\title{
Employee Employer Relationship in Ancient Tamil Literature: With Special Reference to Tirukkural
}

\author{
Dr. Alka Jain* \\ *Asstt. Professor cum Placement Officer, S. S. Jain Subodh Management Institute, Jaipur, Rajasthan, India
}

\begin{abstract}
Employee employer relationship is a sensitive and complex issue, which if not handled properly leads to serious organizational problems. Unfortunately there is no quick and easy formula to use which will provide an instant solution to these problems. The author has explored an ancient Tamil book - Tirukkural, for rediscovering such formulae or codes of conduct of employee employer relationship. Interestingly, a complete theory of employee employer relationship is discovered in the book. Many verses in the book are devoted to this organizational issue by addressing the relationship between a king and his subordinates, who was the supreme employer of that era.
\end{abstract}

Keywords: Employee, employer, employee employer relationship, organizational conflicts, Tirukkural literature

\section{Research Problem}

The study approaches an ancient management handbook „Tirukkural ${ }^{\text {ee }}$ with a thought in mind whether a theory of employee employer relationship exists in the ancient Tamil book. Are these theories relevant in modern business organizations? Is there any new lead from Tirukkural which can be taken forward?

\section{Methods and Material}

The study starts with an exploring approach of studying the ancient book, ,Tirukkural ${ }^{e e}$. Then it is analyzed whether the book throws light on factors of employee employer relationship. Tirukkural has been studied with the help of English, Sanskrit and Hindi translations by eminent scholars. Data has been interpreted in modern terms of employee employer relationship.

\section{An Introduction to Tirukkural}

Tirukkural is an ancient piece of Jain Tamil literature. It was written by Jainacharya Kundkund Ji. It is a collection of verses guiding the reader to lead a happy and ethical life at all platforms and stations of life. It uses spiritual approach to familiarize the readers with 1 . Social topics like friendship, 2. Political topics like qualities of a king or how to win a battle, 3. Management topics like corporate behavior, recruitment techniques and entrepreneurship etc. Not only this, but human psychology is also utilized to explain these concepts to its readers. This is severally called such as Tamil MaRai or, pancham Veda ${ }^{e e}$ - The fifth sacred book see footnote. The book is composed in couplets named ,Kural ${ }^{\mathrm{e}}$. There are 133 chapters in the book explaining three aspects of Prushartha: Virtue, wealth and Love.

\section{Employee Employer Relationship and its Importance}

Employee is a person who is employed for wages or salary, especially at non-executive level. An employer is a person or organization that employs people. It is very important for success of an organization to have a strong employer and employee relationship. A strong relationship brings out the productivity of employees and leads to less employee employer conflict. Loyalty is a bi-product of strong employee employer relationship. Importance of employee employer relationship can be seen in organizational problems like Productivity, employee loyalty, conflict reduction, motivating your employees, setting goals, delegation, effective communication and embracing Equality. Modern management scholars opine that "Strong employment relations create a pleasant atmosphere within the work environ". (http://www.business2community.com/strategy/strongemployeeemployer-relationship)

\section{Employee Employer Relationship Theory of Tirukkural}

Employee employer relationship has been discussed in scattered verses of the $68^{\text {th }}, 69^{\text {th }}$ and $70^{\text {th }}$ chapters of Tirukkural.

\section{(Chapter 69)}

Verse 1:"नातिदूरसमीपस्थोनृपंसेवेतपंडित:शीतबाधानिर्वृत्यर्थंयथाग्निम्सेवतेजन:]]"

Meaning: whoever approaches the king (superior employers) his approach should not be too personal or too formal. He should be advised to behave as if he is being warmed by a fire; hence he should not go too near neither very far from the fire.

Verse 2:"नृपस्याभीष्टवस्तूनांलालसांत्यजदूरत:.ततोवैभवसंप्राप्तेरेषमंत्रोSस्त्यबाधित:]]" Meaning; if you wish to please your employer, then never wish for those things which he loves/does not want to give away. The message of the verse is not to be competitive with your employer, only then your services will be duly rewarded.

\footnotetext{
Verse 3:"विरागंभूपते; प्राप्रुंयदित्वंनैववान्छसि, मुंचतर्हिमहादोषान्यतः शंकास्तिदुस्त्यजा]]"
}

Meaning "If you do not want to displease the employer then you need to keep yourself above any flaw, because once the doubt in your superiores mind arises, it is very difficult to removed (the doubt). Ensure to comply with services standards. Any slip can spell doom. 


\section{International Journal of Science and Research (IJSR) \\ ISSN (Online): 2319-7064}

Index Copernicus Value (2013): 6.14 | Impact Factor (2014): 5.611

Verse 5:"निलीयशृणुयात्रैववार्तांकान्चिन्महीपते :यत्नश्चापिनकर्तव्यस्तदुहुस्यावबोधने]]" Never share matters of confidentiality with others unless told by the king (employer). Do not try to listen to the communication of your superiors which is not meant for you. Also do not try to get knowledge of those facts which are kept secret from you. You should know a secret only when it is shared with you.

Verse

6:“कालोSस्तिसाम्प्रतंकीदृक्प्रकृतिश्चास्यकीदृशी,

इतिपूर्वंसमालोच्यवाचातदनुमोदयेत]]'

While conveying news of unpleasant nature, gauge his mood and wait for right moment and speak in a manner that pleases him. You should please a king by using the words that suit the situation and the reference.

Verse $7:$ "मोदोभवतिया: श्रुत्वावाचस्ताव्याहरेन्नृपम, याभिश्चकोS पिलाभोनपृच्छयमानोनतावदेत्]]"

Discuss only those issues which please the king, do not discuss the issues which may displease him even if he asks about them. Hence you should sort out the information that pleases the employer and good for him and weed out others.

Verse 10: "घनिष्ठोदृढमित्रंचवर्ततेममभूपति:इतिमत्वापकृत्येयोरातोनूनंसनश्यति]]" Never lower your dignity in deeds with the assumption that my association with the king is long and trusted. This will surely bring fall.
(Chapter 70)

$\begin{array}{lll}\text { Verse } & 3: & \text { "स्वामिलाभाययेनात्तोभारोभूपतिमंडले, } \\ \text { आवश्यकंहितद्वाण्यांपाण्डित्यंसर्वतोधिकम्]]" } & \end{array}$

The one who takes the responsibility of conveying the kinges message to other kings, he should be compulsorily wisest of all.

Verse 5:"संक्षेपभाषाणंवाण्यांमाधुर्यंकटूवभाषणम, साधानैरैतै:कुर्वन्तिस्वामिनोहितम्]]"

There are only three means by which an ambassador can benefit his own king: 1 . to be able to give detailed information in brief sentences 2. Sweet talk 3. Be alert and should not use indecent language

Verse 6: "प्रभावोत्पादिकावाणीवैदुष्यंसमयज्ञता, प्रत्युत्पन्नमतित्वंचदूतस्यप्रथमगुणा:]]" Influential speech, intellect and intelligence, calmness, a sharp mind to see and foresee correct timing of his action/speech are the primary qualities of an ambassador.

Verse 9:आवेशादपिनब्रूतेदुर्वाक्यंयोविचक्षण:परराष्ट्रेसएवास्तियोग्यशासनहारक:]]"

Those who are wise enough, do not use indecent language, such are the people who can be chosen for conveying messages to other kings.

\section{Data Interpretation and Analysis}

\begin{tabular}{|c|c|c|}
\hline $\begin{array}{l}\text { Element of Employee } \\
\text { Employer Relationship }\end{array}$ & $\begin{array}{l}\text { Tirukkural Theory of Employee Employer } \\
\text { Relationship (Sanskrit) }\end{array}$ & $\begin{array}{c}\text { Tirukkural Theory of Employee Employer } \\
\text { Relationship (English) }\end{array}$ \\
\hline $\begin{array}{l}\text { Closeness between } \\
\text { employee and employer }\end{array}$ & नातिदूरसमीपस्थोनृपंसेवेतपंडित:, शीतबाधानिर्वृत्यर्थंयथाग्निम्सेवतेजन: & $\begin{array}{l}\text { Whoever approaches the king (employer) his } \\
\text { approach should not be too personal or too formal. } \\
\text { He should be advised to behave as if he is being } \\
\text { warmed by a fire, hence he should not go too near } \\
\text { neither very far from the fire. }\end{array}$ \\
\hline $\begin{array}{l}\text { Disclosing the flaws of an } \\
\text { employee to the employer }\end{array}$ & विरागंभूपते; प्राप्तुंयदित्वंनैववान्छसि, मुंचतर्हिमहादोषान्यत: शंकास्तिदुस्त्यजा & $\begin{array}{l}\text { If you do not want to displease the employer then } \\
\text { you need to keep yourself above any flaw, because } \\
\text { once the doubt in your superior"s mind arises, it is } \\
\text { very difficult to remove (the doubt). Ensure to } \\
\text { comply with services standards. Any slip can spell } \\
\text { doom. }\end{array}$ \\
\hline Secrecy of facts & निलीयशृणुयात्रैववार्तांकान्चिन्महीपते:, यत्नश्चापिनकर्तव्यस्तद्रुह्यस्यावबोधने & $\begin{array}{l}\text { Never share matters of confidentiality with others } \\
\text { unless told by the king (employer). Do not try to } \\
\text { listen to the communication of your superiors which } \\
\text { is not meant for you. Also do not try to get } \\
\text { knowledge of those facts which are kept secret from } \\
\text { you. You should know a secret only when it is } \\
\text { shared with you. }\end{array}$ \\
\hline $\begin{array}{l}\text { Employee's rivalry with } \\
\text { employer }\end{array}$ & नृपस्याभीट्टवस्तूनांलालसांत्यजदूरतः :ततोवैभवसंप्राप्रेषषमंत्रोSस्त्यबाधित: & $\begin{array}{l}\text { If you wish to please your employer, then never } \\
\text { wish for those things which he loves/does not want } \\
\text { to give away. The message of the verse is not to be } \\
\text { competitive with your employer, only then your } \\
\text { services will be duly rewarded. }\end{array}$ \\
\hline $\begin{array}{l}\text { How to give bad news to } \\
\text { the employer }\end{array}$ & $\begin{array}{l}\text { कालोSस्तिसाम्प्रतंकीदृक्प्रकृतिश्चास्यकीदृशी, } \\
\text { इतिपूर्वंसमालोच्यवाचातदनुमोदयेत् }\end{array}$ & $\begin{array}{l}\text { While conveying news of unpleasant nature, gauge } \\
\text { his mood and wait for right moment and speak in a } \\
\text { manner that pleases him. You should please a king } \\
\text { by using the words that suit the situation and the } \\
\text { reference. }\end{array}$ \\
\hline $\begin{array}{l}\text { Selection of topics of } \\
\text { Discussion with an } \\
\text { employer }\end{array}$ & $\begin{array}{l}\text { मोदोभवतिया: श्रुत्वावाचस्ताव्याहरेन्दृपम्, } \\
\text { याभिश्चकोSपिलाभोनपृच्छयमानोनतावदेत् }\end{array}$ & $\begin{array}{l}\text { Discuss only those issues which please the king, Do } \\
\text { not discuss the issues which may displease him } \\
\text { even if he asks about them. Hence you should sort } \\
\text { out the information that pleases the employer and } \\
\text { good for him and weed out others. }\end{array}$ \\
\hline
\end{tabular}


International Journal of Science and Research (IJSR)

ISSN (Online): 2319-7064

Index Copernicus Value (2013): 6.14 | Impact Factor (2014): 5.611

\begin{tabular}{|c|c|c|}
\hline $\begin{array}{l}\text { Taking undue advantage } \\
\text { of good relations with } \\
\text { employer }\end{array}$ & घनिष्ठोदृढमित्रंचवर्ततेममभूपति:, इतिमत्वापकृत्येयोरातोनूनंसनश्यति & $\begin{array}{l}\text { Never lower your dignity in deeds with the } \\
\text { assumption that my association with the king is } \\
\text { long and trusted. This will surely bring fall. }\end{array}$ \\
\hline $\begin{array}{l}\text { Qualities of employer's } \\
\text { ambassadors }\end{array}$ & $\begin{array}{l}\text { स्वामिलाभाययेनात्तोभारोभूपतिमंडले, } \\
\text { आवश्यकंहितद्वाण्यांपाण्डित्यंसर्वतोधिकम् }\end{array}$ & $\begin{array}{l}\text { The one who takes the responsibility of conveying } \\
\text { the kinges message to other kings, he should be } \\
\text { compulsorily wisest of all. }\end{array}$ \\
\hline $\begin{array}{l}\text { Being an effective } \\
\text { ambassador of your } \\
\text { employer }\end{array}$ & $\begin{array}{l}\text { संक्षेपभाषाणंवाण्यांमाधुर्यंकटूवभाषणम्, सुदूता: } \\
\text { साधानैरैतै:कुर्वन्तिस्वामिनोहितम् }\end{array}$ & $\begin{array}{l}\text { There are only three means by which an } \\
\text { ambassador can benefit his own king: } 1 \text {. To be able } \\
\text { to give detailed information in brief sentences } 2 \text {. } \\
\text { Sweet talk } 3 \text {. Be alert and should not use indecent } \\
\text { language }\end{array}$ \\
\hline $\begin{array}{l}\text { Being an effective } \\
\text { ambassador of your } \\
\text { employer }\end{array}$ & प्रभावोत्पादिकावाणीवैदुष्यंसमयज्ञता, प्रत्युत्पन्नमतित्वंचदूतस्यप्रथमगुणा: & $\begin{array}{l}\text { Influential speech, intellect and intelligence, } \\
\text { calmness, a sharp mind to see and foresee correct } \\
\text { timing of his action/speech are the primary qualities } \\
\text { of an ambassador. }\end{array}$ \\
\hline $\begin{array}{l}\text { Qualities of an employer's } \\
\text { representative }\end{array}$ & आवेशादपिनब्रूतेदुर्वाक्यंयोविचक्षण:, परराष्ट्रेसएवास्तियोग्यशासनहारक:]]" & $\begin{array}{l}\text { Those who are wise enough, do not use indecent } \\
\text { language, such are the people who can be chosen } \\
\text { for conveying messages to other kings. }\end{array}$ \\
\hline
\end{tabular}

\section{Conclusion}

Employee and employer relationship is discussed in the book ,Tirukkural ${ }^{\text {ee }}$ and it covers almost all aspects of this problem. Closeness between an employee and the employer, secrecy of facts, good and bad qualities of an employee acting as the employer"s representative, selection of topics of discussion with an employer, taking undue advantage of smooth relationship with boss etc. have been addressed with great seriousness.

\section{Limitations of the Study}

Original text of the book „Tirukkural ${ }^{\text {ee }}$ is in Tamil, but the author has used Sanskrit Hindi and English translations for the purpose of this research paper. It is a well-known fact that a translation can never fully replace the original text. One more problems with these translations is that all of them vary in the format, some of them have used the chapter format and hence the serial of verse differs from those which have used universal pattern of serial number of verses. The Tirukkural era speaks of men only because women were not supposed to go out to work and be a part of the corporate world. Hence we have to generalize all the masculine terms like ,स:तस्य, तेन' etc. to include the women workforce in the theory. Similarly, employers are addressed as male kings only - नृप:भूपति: etc.

\section{Contribution}

Getting benefitted from the knowledge of our ancestors has always enriched the skills of mankind. By understanding basics of successful employee employer relationship may lead us towards a sophisticated and disciplined economy. A disciplined economy denotes a prosperous economy which fulfils its social responsibility also. Employee Employer Relationship Model of Tirukkural is based on psychological and social effects on employees and employers at workplace.

\section{References}

[1] Dr. Inderraj Baid, „Jain Tamil Sahitya aur Thirukkural $^{\text {ee }}$ Samyaggyan Pracharak Mandal, Jaipur, 1987.

[2] GovindRai Jain Shastri, „KuralKavya ${ }^{e e}$, VitragWani Trust Registered, TikamGArh, M.P., 2001.

[3] KaNaaSubramanyam, „Thiruvalluvar and His Thirukkural ${ }^{\text {ee }}$ Bhartiya Jnanpeeth, New Delhi, 1987.

[4] P. S. Sundaram, „The Kural. Penguin Books: London, 1990.

[5] http://www.business2community.com/strategy/strongemployeeemployer-relationship-important-achieve0876781

[6] http://smallbusiness.chron.com/employeremployeerelationship-16737.html retrieved on 15th October, 2015.

[7] http://www.ilo.org/ifpdial/areas-of-work/labourlaw/WCMS_CON_TXT_IFPDIAL_EMPREL_EN/la ng--en/index.htm 